\title{
A HUNDRED YEARS OF SOLITUDE IN MORAL EDUCATION
}

\author{
Bohumil Fiala
}

\begin{abstract}
This article deals with the discussion concerning moral education. The paper tries in brief to look at the attitude to moral education at the end of the $19^{\text {th }}$ century and at the present time.
\end{abstract}

\section{Key words}

Moral education, essence of people, Christianity, postmodernism.

\section{Sto let samoty v mravní výchově}

\section{Resumé}

Tento článek je příspěvkem do diskuse týkající se mravní výchovy. Snaží se stručně ukázat na postoj k mravní výchově na konci 19. století a v současnosti.

\section{Klíčová slova}

Mravní výchova, podstata člověka, křestanství, postmodernismus.

Moral education is needed. That should not be doubted. Opinions that moral education is not necessary and that man should develop without any manipulation should be considered as minority ones. As long as man lives in the society of other people, he/she has to be manipulated in a certain way. Morals are a social phenomenon. From the historical point of view there were always discussions what should be understood under the term "morals". From the point of view of the history of ethical thinking we can find various views of the way man should behave and act. I consider that discourse as permanent and never ending. Such dialogue relates to the merit of man and his coexistence with other people.

At the beginning of this paper I would like to say that I do not agree with opinions that morals of the society were, are or will be in some crises. These 
apocalyptic views excite in feeling that in some periods of the life of mankind people behaves in a more moral way that in others. In every stage people encountered problems, every period had many positives and negatives as well, every stage had its boom and recession. There is nothing immoral on that. It is a part of the order of the course of the world. Therefore questions of morals are necessary to be comprehended in such context.

Within the public democratic education these discussions were held, are being held and provided we want to maintain our culture they have to be held. Do not let us be afraid of such reasoning as they are part of our nature. Let us keep in mind that never fixed and invariable moral values and standards will be found, however, let us reflect those that proved good in the history of mankind, no matter what their origin are and how old they are.

At the end of the $19^{\text {th }}$ century in the Danubian monarchy similar questions connected to moral education as we are solving now were being solved; e.g. V. Gabriel in his "Upbringing in the Family. For Our Parents and Educators" devotes to those questions great attention. ${ }^{1}$ We can find out that he ranges moral upbringing (in his terminology moral education) as a subset of the set family upbringing. Here we see the difference of the present concept when these problems are far more related to institutions. In the course of more than one hundred years this significant change has been made, as for my opinion. Nowhere there has been stated though that this will be the permanent state, perhaps in future this ration will change again and moral education (upbringing) will again become one of the fundamental chapters of the family upbringing. Accentuating more the moral education (upbringing) in the family and making parents more responsible for that upbringing seems to me far more natural than it is nowadays when these competences are far more adopted by educational institutions.

The roots of this approach can be seemed in the $18^{\text {th }}$ century at Jean Jacques Rousseau (1712-1787). This educationalist is a typical representative of intellectuals in Johnson's conception. ${ }^{2}$ Rousseau believed that changes are possible to be reached on the base of politic process. Johnson describes the period of his life when he put away all five children who he had with his spouse Tereza Levasseure to Hôpital des Enfants - Trouvés. Father of modern pedagogy needed to justify and advocate such "non-pedagogical" conduct of his. His act is an

\footnotetext{
${ }^{1}$ GABRIEL, V. Výchova rodinná. Pro rodiče a vychovatele. Praha: Libuše, Matice zábavy a vědění, 1896.

${ }^{2}$ JOHNSON, P. Intelektuálové. Praha: Návrat domů, 1995. ISBN 80-85495-50-3.
} 
organical part of the process from which the theory on politics and the role of state worked out by him originated. Rousseau's state is not only authoritarian; it is also totalitarian as it controls all aspects of human activity, including thinking. By the social contract man was to bind himself to "submit himself even with all his rights to the society as the whole". This approach required totalitarian submission. It is a new outline of Lenin's "democratic centralism". Laws worked out according to the common will must have an a priori moral authority. Educational process became a key to the success of cultural engineering which the state needed to be acceptable and successful; the centre line of Rousseau's ideas was a citizen as a child and a state is a parent. The political process and a new kind of the state which creates this process are a universal remedy for diseases of mankind. Politicians will manage everything. By that Rousseau prepared groundwork for the fundamental disillusion and foolishness of the twenties century. ${ }^{3}$

V. Gabriel understands by moral education (in no way he distinguishes from other authors) upbringing to love, respect and esteem, virtue, order, propriety and courtesy, honesty chariness and frugality, truth and love for fatherland (in the language of that period a bit different words are used). ${ }^{4}$

From his "Upbringing in the Family" we can read that more than one hundred years ago he pointed at negative phenomenon at children and youth which could be seen nowadays as well (maybe in small differences). For example: "Often even good children after leaving school are led astray by bad companions and into the whirl of various profligacy pulled. Many times we see fourteen or fifteen years old young lads with cigars playing cards somewhere on the balk behind the bush, or in the pub with girls hardly left school dancing. On that matter the local moral police should watch that for not that happen.

Smoking is a vice, and who has learned that in the youth then he cannot break away from that. Smoking influences the health in a killing way and threatens greatly as much as drinking alcohol drinks threatens chastity of growing lads.

On the top of those young smokers start learning to lavish uselessly hardearned money, which mainly for the poor class, working one has as for wealth unwelcome consequences. Many times a young worker does not have a bit to

\footnotetext{
${ }^{3}$ JOHNSON, P. Intelektuálové. Praha: Návrat domů, 1995. ISBN 80-85495-50-3. s. 28.

${ }^{4}$ GABRIEL, V. Výchova rodinná. Pro rodiče a vychovatele. Praha: Libuše, Matice zábavy a vědění, 1896.
} 
eat and by what he feed himself for work. But the feeding for his pipe must be got, take where you can.

By puppet theatres the delicate roots of a fragile flower of innocence are burrowed under, as children often hear here talks of Punches which not even in the barracks are heard.

And what about the adolescent youth that work in factories? Who heard here talks and songs of children just left the school and noticed hollow eyes and pale cheeks of the girls employed there, he consents to that they are lilies, by the frost of depravity stricken from which the drift of life already the pollen of innocence blew off." ${ }^{5}$

As long as we are going to analyse his standpoint to moral education we found out that in many aspects he does not distinguish from current standpoints. For example: "Only the man free can become the moral oned", or "to keep up the word already given and truth to love". ${ }^{6}$

I repeat, in one hundred years the view on the states and the role of the family in moral education and on the basic source of morals has changed fundamentally. In that I would see the principled problem which we should solve. "Morals are higher and exalts more than science and knowledge. Knowledge is only the means, morals are the aim". ${ }^{7}$ I assume that at the beginning of the third millennium, in the consequence of the development from the second half of the twentieth century, this ratio is reverse. Nowadays above all knowledge and science is talked about, knowledge and skills which students are to have.

If we refer to the family upbringing, in many cases the family does not fulfil its traditional educational role see. "Childhood, family and old-age in the history of Europe". 8

The fundamental problem in moral education lies in my opinion in the source of morals. Moral education is not only based explicitly on Christianity, even though many Christian elements which are rooted in our culture are transformed into moral education. For example the already mentioned author places "cultivating volition or love" (he places love among all virtues on the first

\footnotetext{
${ }^{5}$ GABRIEL,V. Výchova rodinná. Pro rodiče a vychovatele. Praha: Libuše, Matice zábavy a vědění, 1896. s. 307.

${ }^{6}$ GABRIEL, V. Výchova rodinná. Pro rodiče a vychovatele. Praha: Libuše, Matice zábavy a vědění, 1896. s. 88, 103.

${ }^{7}$ GABRIEL, V. Výchova rodinná. Pro rodiče a vychovatele. Praha: Libuše, Matice zábavy a vědění, 1896. s. 88.

${ }^{8}$ HORSKÁ, P. - KUČERA, M. - MAUR, E. - STLOUKAL, M. Dětství, rodina a stář́ v dějinách Evropy. Praha: Panorama, 1990.
} 
place) in the famous first letter saint apostle Paul to the Corinthians where he speaks on the position of love. ${ }^{9}$ By the fact that at the beginning of the twentyfirst century the source is absent the process balances on the clay legs.

From the philosophical view firstly from post modernistic positions (postmodernisms is a concept being pushed at attempts to indicate and also to describe the wide changes the source of which became to be acknowledged in an increased extent in the second half of the twentieth century).

The Czech philosopher, V. Bělohradský, summarizes basic motives of post modern thinking, among others also by the following way. "It is necessary to extricate from the power of the myth on the final solution, on punishment and rewards which is the base of modern philosophy of the history. This myth founds domination of man over the nature by reducing the world only on some kind of object, a kind of a examination in which the one who succeeds will acquire immortality. Patočka speaks about the "happy end" which philosophy contrives constantly. How the reality became a fable - so the greatest Nietzsche's question sounds. To live without the happy end, that is a big post - a modern motif. Its consequence is "de-historicizing" of sociability. Human social relations are extricating from subordination to the historical projects into which it was thrown by the modern philosophy of the history. The sense is established in human communication. In the cyclical period of time and not in the projects of the final solution. ${ }^{10}$ From the philosophical standpoint it is the aspect deriving its significance from the history of the twentieth century. Nevertheless from the point of view of pedagogy it brings fundamental difficulties. Honestly, without the myth and final solutions, without the stress and awards, without the happy end moral education can be realized in a very difficult way. Naturally that it proceeds. But it leans on the swamp subsoil.

The majority of human beings behave in a moral way as it is advantageous for them. This theory of moral advantageousness penetrates our whole life. Naturally there exist individuals who behave morally on the basis of moral principles, to behave so not because that it is advantageous, but for the principle. Based on the "higher moral principle" to be willing even to sacrifice the life.

J. F. Lyotard claims that the levels of statements of the world and ways of denomination of the relation of man to it are so different that they lose recipro-

\footnotetext{
${ }^{9}$ GABRIEL, V. Výchova rodinná. Pro rodiče a vychovatele. Praha: Libuše, Matice zábavy a vědění, 1896. s. 94.

${ }^{10}$ BĚLOHRADSKÝ, V. Přrirozený svět jako politický problém. (Esej o člověku pozdní doby). Praha: Československý spisovatel, 1991. ISBN 80-202-0279-X. s. 136.
} 
cal comprehensibility. By that also the possibility of the approach to the world as the whole vanishes and whatever certainty die away for the current man. ${ }^{11}$

Many people as I have mentioned need firm moral codexes from which it implies how they should behave and not only that.. The majority needs to know why it is advantageous for them to behave according to those codexes and on the contrary why it is disadvantageous for them to ignore them.

D. Šimek in "Selected Problems of the Theory of Education of Adults" refers to the fact that moral codexes in Europe practically till the present time have not exceeded the limitation given by the limits of the biblical "Ten Commandments." Moreover he states that this "Ten Commandments" by far is not the original work of the Israelites from the period of the exodus and also in this respect the authors of the texts utilized from the cultural heritage of Mesopotamia and Egypt. Moral norms of "Ten Commandments" reflect the level of moral, as well as economic, legal and mainly religious cognition of its period. In his text D. Šimek further shows that the moral codex of a builder of communist admitted at the XXII. Congress of the Soviet Union thought it comes out from dialectical-historical and dialectical-materialistical principles (which are strictly atheistic), with its general structure does not differ in principle too much from the "Ten Commandments".

T. Halik, our current most significant sociologist of religion, in the majority of his works points out the fact that traditional European religion, Christianity which is one of the European pillars historically is losing its dominant position, it recedes from the majority of areas which it addressed before. According to him it is an illusion to assume that it will recover its positions. He speaks about the fact that Christianity will be one of the jigsaws in the varied European culture. It will address not insignificant group of believers, nevertheless it will already not be and would not have ambitions to be a religion of the whole Europe. ${ }^{12}$

The European Court for Human Rights in Strasbourg from November $4^{\text {th }}$ 2009 decided that Christian crosses in state schools endanger freedom of religion and education. The judges thus complied with the complaint of a woman who addressed them as she thought that the Italian state does not enable to

${ }^{11}$ LYOTARD, J. F. O postmodernismu. 1. vyd. Praha: Filosofia, 1993. ISBN 80-7007-047-1. ${ }^{12}$ viz. HALÍK, T. Dotkni se ran. Spiritualita nelhostejnosti. 1. vyd. Praha: NLN, 2008. ISBN 978-80-7106-979-9. HALÍK, T. Oslovit Zachea. 1. vyd. Praha: NLN, 2003. ISBN 80-7106-547-1. HALÍK, T. Noc zpovědníka. Paradoxy malé víry v postoptimistické době. 1. vyd. Praha: NLN, 2005. ISBN 80-7106-777-6. HALÍK, T. Vzdáleným nablízku. Vášeň a trpělivost v setkání víry s nevírou. 1. vyd. Praha: NLN, 2007. ISBN 978-80-7106-907-2. 
educate children in the secular environment. It is the truth that the majority of the Italians unified in the disapproval to that verdict. The verdict however shows the position of Christianity in our present European culture. This "European" decision gives us the answer how to teach moral education. To avoid everything what could irritate someone. Education should be absolutely impartial and in the sense of political correctness in the broadest sense of meaning. The whole mentioned event was commented by the Italian president S. Berlusconi in words that the verdict is an irrational attempt to "deny European Christian roots". The second man of the Vatican City, the state secretary cardinal T. Bertone presented the statement "Europe of the third millennium refuses takes away from us the most precious symbols and gives us only pumpkins for the festival of Halloween". ${ }^{13}$

The French writer R. Merle in his sci-fi novel "Melville" describes the country after the nuclear catastrophe. Isolated groups of the people were saved. Heroes of the book think about the way of living in the existing situation. Even though they all have experience with the pluralistic democratic society, they decide to set their life on the order and in the sense of this order to bring up their offspring. ${ }^{14}$

The process of moral education proceeds in the relation with moral and value development of the individuality. O. Roche speaks about the education to pro-sociability. Pro-sociability conduct is generally understood as a type of the behaviour when one can help or be good to another person, without expecting any outer reward. That education already appeared in the $2^{\text {nd }}$ half if the last century and is among others a sad reaction on those elements of the development of the society which support a general trend of man to pragmatic individualism. That except advantages which can be brought to an individual can of course be or respectively it is for man a certain risk. The systems heading here thus try to build on another tendency, the altruistic tendency. ${ }^{15}$

This concept seems to me superficial and idealistic. I repeat, the majority of individuals behaved, behaves and will behave pragmatically. It relates to the principle of man.

${ }^{13}$ Křiže v italských školách podle Štrasburku ohrožují svobodu vyznání. [online]. Publikováno 4. 11. 2009 [cit. 10. 11. 2009]. Dostupné z: http://www.ct24.cz/svet/71535-krize-v-italskychskolach-podle-strasburku-ohrozuji-svobodu-vyznani/

${ }^{14}$ MERLE, R. Malevil. Praha: Svoboda, 1992. ISBN 8020502424.

${ }^{15}$ ROCHE, O. Etická výchova. Bratislava: Orbis pictus Istropolitana, 1992. ISBN 80-7158001-5. 
I would like to refer to the work of R. Palouš "Time of Education" and "Philosophy of Education" when he attempts to map individual views on education and refers to that "anchoring" in the educational process. ${ }^{16}$

\section{Conclusion}

By the conclusion itself I would like to explain why I have entitled the paper. "A Hundred Years of Solitude in Moral Education" which I have borrowed from the world-famous book by G. G. Marquez. The history as if it repeated, we are solving the same fundamental problems, we are not able to analyse the past, at the same time we absent from ourselves and from the worlds as well and we do not try to understand why it is like that. ${ }^{17}$

The concept of the moral education from the nineteenth century as I have briefly drafted is considered by me as very incentive and inspiring in the sphere of the concrete principle. Otherwise said, without any regard to the Christian orientation of that period education, I have to behave in a moral way just because of that.

I am unable in this paper a solution, I wanted only to refer to "throwing away" anchors and offering seemingly quite surely a nice and attractive model of moral education which is based on lofty intellectual phrases, but in principle icy empty.

\section{Literature}

[1] BĚLOHRADSKÝ, V. Přrrozený svět jako politický problém. (Esej o člověku pozdní doby). Praha: Československý spisovatel, 1991. ISBN 80-202-0279-X.

[2] GABRIEL, V. Výchova rodinná. Pro rodiče a vychovatele. Praha: Libuše, Matice zábavy a vědění, 1896. ISBN neuvedeno.

[3] HALÍK, T. Dotkni se ran. Spiritualita nelhostejnosti. 1. vyd. Praha: NLN, 2008. ISBN 978-80-7106-979-9.

[4] HALÍK, T. Oslovit Zachea. 1. vyd. Praha: NLN, 2003. ISBN 80-7106-547-1.

[5] HALÍK, T. Noc zpovědníka. Paradoxy malé víry v postoptimistické době. 1. vyd. Praha: NLN, 2005. ISBN 80-7106-777-6.

[6] HALÍK, T. Vzdáleným nablízku. Vášeň a trpělivost v setkání víry s nevírou. 1. vyd. Praha: NLN, 2007. ISBN 978-80-7106-907-2.

\footnotetext{
${ }^{16}$ PALOUŠ, R. K filosofii výchovy. 1. vyd. Praha: Státní pedagogické nakladatelství, 1991. ISBN 80-04-25390-3.

${ }^{17}$ MARQUEZ, G. G. Sto roků samoty. Praha: Odeon, 2006. ISBN 80-207-1215-1.
} 
[7] HORSKÁ, P. - KUČERA, M. - MAUR, E. - STLOUKAL, M. Dětství, rodina a stárí v dějinách Evropy. Praha: Panorama, 1990. ISBN 80-7038011-X.

[8] JOHNSON, P. Intelektuálové. Praha: Návrat domů, 1995, ISBN 80-8549550-3.

[9] Kř́že v italských školách podle Štrasburku ohrožují svobodu vyznání. [online] Publikováno 4. 11. 2009 [cit. 10. 11. 2009]. Dostupné z: http://www.ct24. cz/svet/71535-krize-v-italskych-skolach-podle-strasburku-ohrozuji-svoboduvyznani/

[10] LYOTARD, J. F. O postmodernismu. 1. vyd. Praha: Filosofia, 1993. ISBN 80-7007-047-1.

[11] MARQUEZ, G. G. Sto roků samoty. Praha: Odeon, 2006. ISBN 80-2071215-1.

[12] MERLE, R. Malevil. Praha: Svoboda, 1992. ISBN 8020502424.

[13] PALOUŠ, R. K filosofii výchovy. 1. vyd. Praha: Státní pedagogické nakladatelství, 1991. ISBN 80-04-25390-3.

[14] PALOUŠ, R. Čas výchovy. Praha: SPN, 1991. ISBN 80-04-25415-2.

[15] ROCHE, O. Etická výchova. Bratislava: Orbis pictus Istropolitana, 1992. ISBN 80-7158-001-5.

[16] ŠIMEK, D. Vybrané teorie výchovy dospělých. Olomouc: Univerzita Palackého, 1991. ISBN 80-7067-008-8.

PhDr. Bohumil Fiala, Ph.D.,

Slezská univerzita v Opavě,

Obchodně podnikatelská fakulta v Karviné 